Article

\title{
Offshore Neopycnodonte Oyster Reefs in the Mediterranean Sea
}

\author{
Lorenzo Angeletti ${ }^{1, *}$ (D) and Marco Taviani ${ }^{1,2,3}$ \\ 1 ISMAR-CNR, U.O.S. Bologna, via Gobetti 101, I-40129 Bologna, Italy; marco.taviani@bo.ismar.cnr.it \\ 2 Biology Department, Woods Hole Oceanographic Institution, 266 Woods Hole Road, \\ Woods Hole, MA 02543, USA \\ 3 Stazione Zoologica Anton Dohrn, Villa Comunale, 80121 Napoli, Italy \\ * Correspondence: lorenzo.angeletti@bo.ismar.cnr.it
}

Received: 1 January 2020; Accepted: 4 March 2020; Published: 5 March 2020

Abstract: Oysters are important ecosystem engineers best known to produce large bioconstructions at shallow depth, whilst offshore deep-subtidal oyster reefs are less widely known. Oyster reefs engineered by Neopycnodonte cochlear (family Gryphaeidae) occur at various sites in the Mediterranean Sea, between 40 and $130 \mathrm{~m}$ water depths. Remotely Operated Vehicle surveys provide new insights on this rather neglected reef types with respect to their shape, dimensions and associated biodiversity. We suggest that these little contemplated reefs should be taken in due consideration for protection.

Keywords: oyster reef; mesophotic; Mediterranean Sea

\section{Introduction}

Oysters are important ecosystem engineers distributed worldwide, with a tendency to aggregate in large numbers creating bioconstructions of considerable lateral and vertical extent such as beds, banks, up to reefs $[1,2]$. Oyster reefs sensu lato play a pivotal ecological role by enhancing biodiversity, fishery and coastal protection, among others [2-12]. Oyster reefs best develop at shallow depths in estuarine, bay or lagoonal settings, as well as in marine shallow subtidal situations [2,13-15]. True oysters (Ostreoidea) may have been arisen at the Permian-Triassic boundary (revised in [16]), with families Ostreidae and Gryphaeidae, and their reefs being positively documented in the Mesozoic and Cenozoic [2,17-24].

At present, the main reef-builders in European waters are members of the family Ostreidae (Ostrea edulis Linnaeus, 1758, and Crassostrea spp.) constructing reefs at intertidal to very shallow $(0-20 \mathrm{~m})$ water depths [25-34]. Analogous bioconstructions engineered by Ostreidae are common in the European Cenozoic record [23,35,36].

Gryphaeidae are also known to produce relevant bioconstructions in European waters, but at deeper depths (> $30 \mathrm{~m}$ ), and this was the case also in the past, since at least the Middle Miocene (e.g., Neopycnodonte navicularis, [36-39] among others). Two extant taxa engineering oyster aggregations in the Mediterranean and Atlantic, which could, at times, be identified as reefs, are Neopycnodonte cochlear (Poli, 1795) and Neopycnodonte zibrowii Gofas, Salas and Taviani, 2009. The latter settles on hard substrates at bathyal depths (ca. $300-800 \mathrm{~m}$ ) forming encrustations, rims and occasional small reefs [40-48]. N. cochlear is widespread in the Mediterranean at intermediate water depths (ca. 30-150 m), mainly under mesophotic conditions, or even deeper in the NE Atlantic [46,49], and also colonizes dark submarine caves [50]. It forms aggregations in the Mediterranean offshore and its capability to build up or contribute to reefs is recognized [46,51,52]. However, there is a substantial lack of knowledge regarding this intermediate (mesophotic) oyster, and only a few literature records are available on Neopycnodonte cochlear occurrences (e.g., [52,53]). 
Oyster reefs are of paramount importance worldwide (e.g., [54-58]), and are considered under several protection and management measures (e.g., Habitat Directive: Council Directive 92/43/EEC). According to the EUR28 interpretation manual of the Habitat Directive for the class "1170 Reefs", it can be defined as reef any biogenic (concretions, encrustations, and bivalve beds originating from dead or living animals) or geogenic (reefs originating on non-biogenic substrate such rocks, boulders, etc.) structure arising from the seafloor [59]. Oyster reefs can raise the height of the seafloor from $0.15 \mathrm{~m}$ up to $6 \mathrm{~m}$ (e.g., Crassostrea virginica reefs in the US coasts and Ostrea edulis reefs in the Black Sea, respectively $[60,61])$.

Here, we describe $N$. cochlear reefs identified by Remotely Operated Vehicle (ROV) surveys in the Adriatic and Ionian seas offshore the Apulian margin of Italy (Figure 1).

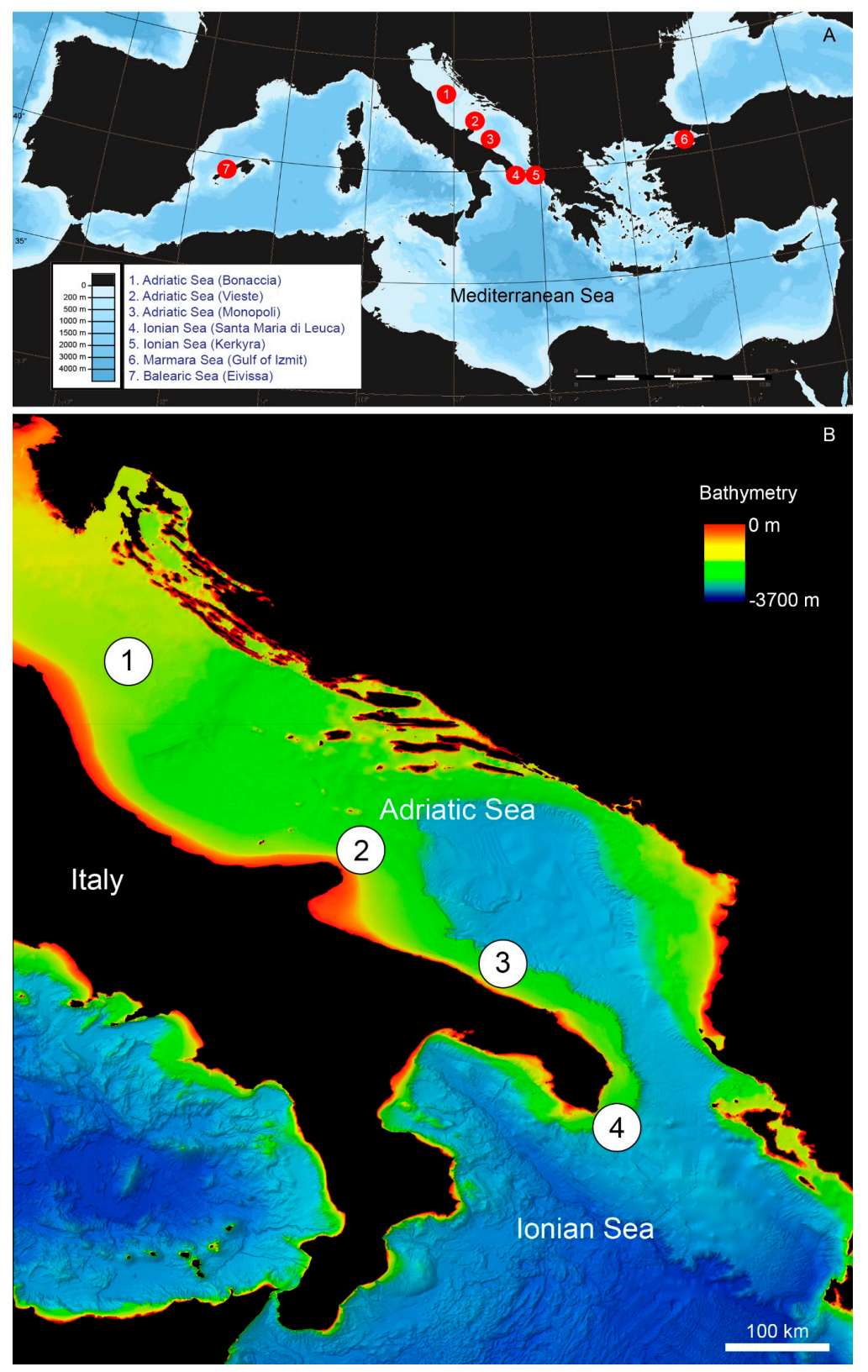

Figure 1. (A) Location map of Mediterranean Neopycnodonte cochlear reefs (red dots) targeted by ROV surveys and discussed in the text; also shown are sites in the SE Adriatic (Greece, Kerkyra), Marmara Sea (Gulf of Izmit) and Baleares (off Eivissa) which produced compelling evidence of such oyster aggregations through bottom sampling. (B) Close-up of the SW Adriatic and N Ionian areas with localisation of main reef sites there. Bathymetry from [62]. 


\section{Materials and Methods}

Several cruises have been carried out in the study areas that evidenced the occurrence of Neopycnodonte cochlear reefs. Remote Operated Vehicle (ROV) dives surveyed the SW Adriatic and N Ionian oyster sites (Figure 1, Table 1). We used an ROV Pollux III (Global Electric Italiana) equipped with a low-resolution CCD video camera for navigation and a high-resolution ( $2304 \times 1296$ pixels) video camera. Three laser beams, each $20 \mathrm{~cm}$ apart, provided the scale bar on the videos. The ROV was equipped with an underwater acoustic tracking system that gives position and depth every second. Still-photo footage, one frame every $10 \mathrm{~s}$, was analysed by the VLC freeware software providing taxonomic information. Macro- $(>2 \mathrm{~cm})$ and mega-benthic organisms were identified to the lower possible taxonomic rank. Taxa unidentifiable at species level from images alone were categorized as morphological categories (e.g., [63,64]). Taxonomic classification adheres to the World Register of Marine Species database [65]. Species densities were calculated using three photos selected at random, showing live Neopycnodonte cochlear reefs, from each transect. ROV exploration was primarily for scientific surveys to monitor the environmental status of marine ecosystems in Italian waters (Marine Strategy Framework Directive).

Table 1. Site locations metadata.

\begin{tabular}{|c|c|c|c|c|c|c|}
\hline Site & $\begin{array}{l}\text { Collection } \\
\text { Date }\end{array}$ & Station & $\begin{array}{l}\text { Lat N-Long } \\
\text { E Start }\end{array}$ & $\begin{array}{l}\text { Lat N-Long } \\
\text { E End }\end{array}$ & $\begin{array}{c}\text { Depth } \\
\text { Min-Max (m) }\end{array}$ & $\begin{array}{l}\text { Dive Length } \\
\text { (m) }\end{array}$ \\
\hline Bonaccia & 13 August 2017 & MS17_III_110 & $\begin{array}{l}43^{\circ} 35.50^{\prime}- \\
14^{\circ} 20.11^{\prime}\end{array}$ & $\begin{array}{l}43^{\circ} 35.23^{\prime}- \\
14^{\circ} 20.44^{\prime}\end{array}$ & $77-83$ & 1079.93 \\
\hline Vieste & $\begin{array}{c}10 \text { November } \\
2015\end{array}$ & MS15_47 & $\begin{array}{l}41^{\circ} 59,62^{\prime}- \\
16^{\circ} 15,14^{\prime}\end{array}$ & $\begin{array}{l}41^{\circ} 59,68^{\prime}- \\
16^{\circ} 15,13^{\prime}\end{array}$ & $55-75$ & 804.72 \\
\hline Vieste & $\begin{array}{c}10 \text { November } \\
2015\end{array}$ & MS15_48 & $\begin{array}{l}42^{\circ} 00.81^{\prime}- \\
16^{\circ} 11.13^{\prime}\end{array}$ & $\begin{array}{l}42^{\circ} 00.78^{\prime}- \\
16^{\circ} 11.13^{\prime}\end{array}$ & $48-49$ & 58.70 \\
\hline Vieste & $\begin{array}{l}11 \text { November } \\
2015\end{array}$ & MS15_62 & $\begin{array}{l}42^{\circ} 01.94^{\prime}- \\
16^{\circ} 10.24^{\prime}\end{array}$ & $\begin{array}{l}42^{\circ} 01.84^{\prime}- \\
16^{\circ} 10.25^{\prime}\end{array}$ & $60-66$ & 139.52 \\
\hline Vieste & $\begin{array}{c}11 \text { November } \\
2015\end{array}$ & MS15_63 & $\begin{array}{l}42^{\circ} 01.02^{\prime}- \\
16^{\circ} 11.75^{\prime}\end{array}$ & $\begin{array}{l}42^{\circ} 00.95^{\prime}- \\
16^{\circ} 11.79^{\prime}\end{array}$ & $50-52$ & 316.75 \\
\hline Vieste & $\begin{array}{c}11 \text { November } \\
2015\end{array}$ & MS15_67 & $\begin{array}{l}41^{\circ} 59.60^{\prime}- \\
16^{\circ} 15.14^{\prime}\end{array}$ & $\begin{array}{l}41^{\circ} 59.48^{\prime}- \\
16^{\circ} 15.23^{\prime}\end{array}$ & $52-72$ & 255.95 \\
\hline Monopoli & 5 August 2017 & MS17_II_180 & $\begin{array}{l}41^{\circ} 00.19^{\prime}- \\
17^{\circ} 24.25^{\prime}\end{array}$ & $\begin{array}{l}40^{\circ} 59.85^{\prime}- \\
17^{\circ} 24.89^{\prime}\end{array}$ & 95-102 & 1685.84 \\
\hline Monopoli & 15 August 2017 & MS17_III_115 & $\begin{array}{l}41^{\circ} 04.17^{\prime}- \\
17^{\circ} 18.15^{\prime}\end{array}$ & $\begin{array}{l}41^{\circ} 04.38^{\prime}- \\
17^{\circ} 18.24^{\prime}\end{array}$ & $85-87$ & 1039.10 \\
\hline $\begin{array}{l}\text { Santa Maria di } \\
\text { Leuca }\end{array}$ & 31 July 2017 & MS17_II_115 & $\begin{array}{l}39^{\circ} 44.02^{\prime}- \\
18^{\circ} 22.26^{\prime}\end{array}$ & $\begin{array}{l}39^{\circ} 44.27^{\prime}- \\
18^{\circ} 22.12^{\prime}\end{array}$ & 70-113 & 1179.90 \\
\hline $\begin{array}{l}\text { Santa Maria di } \\
\text { Leuca }\end{array}$ & 31 July 2017 & MS17_II_117 & $\begin{array}{l}39^{\circ} 42.31^{\prime}- \\
18^{\circ} 21.31^{\prime}\end{array}$ & $\begin{array}{l}39^{\circ} 42.48^{\prime}- \\
18^{\circ} 21.68^{\prime}\end{array}$ & $90-125$ & 1200.00 \\
\hline Kerkyra Island & 3 May 2006 & $\begin{array}{c}\text { CR83 } \\
\text { (Epibenthic } \\
\text { haul) }\end{array}$ & $\begin{array}{l}39^{\circ} 46.00^{\prime}- \\
19^{\circ} 25.52^{\prime}\end{array}$ & $\begin{array}{l}39^{\circ} 47.22^{\prime}- \\
19^{\circ} 25.42^{\prime}\end{array}$ & 77-99 & $\mathrm{n} / \mathrm{a}$ \\
\hline Gulf of Izmit & $\begin{array}{l}19 \text { September } \\
2005\end{array}$ & GRA02 (Grab) & $\begin{array}{l}40^{\circ} 44.00^{\prime}- \\
29^{\circ} 27.00^{\prime}\end{array}$ & - & 56 & $\mathrm{n} / \mathrm{a}$ \\
\hline Eivissa Island & 15 April 2004 & $\begin{array}{c}\text { COBAS-78 } \\
\text { (Epibenthic } \\
\text { haul) }\end{array}$ & $\begin{array}{l}38^{\circ} 45.99^{\prime}- \\
01^{\circ} 18.05^{\prime}\end{array}$ & $\begin{array}{l}38^{\circ} 46.74^{\prime}- \\
01^{\circ} 19.34^{\prime}\end{array}$ & $94-96$ & $\mathrm{n} / \mathrm{a}$ \\
\hline
\end{tabular}

Other Mediterranean sites not surveyed using ROVs proved to host abundant $N$. cochlear valves on the sea-bottom, suggesting the existence of related reefs (Figure 1, Table 1). Large volume Van Veen grabs and epibenthic hauls provided samples of oyster specimens from Kerkyra Island (SE Adriatic), Eivissa Island (Balearic Sea), and the Gulf of Izmit (Marmara Sea) [66]. 


\section{Results}

\subsection{General Features of Neopycnodonte cochlear Reefs}

The Neopycnodonte cochlear reefs surveyed in this research represent various typologies in terms of shape and dimension (Figures 2 and 3). Since based upon ROV observations, their thickness could not be assessed with precision and larger reefs could, in fact, represent encrustations of the underlying substrate by a few generations of grypheid oysters (Figures 2-4).

(i) At Bonaccia in the northern Adriatic Sea (Figure 1), N. cochlear bioconstructions (Figure 2a,b) cover 4-5 $\mathrm{m}$ in lateral extension (length and width) and reach ca. $2 \mathrm{~m}$ in height by likely encrusting over bedrock substrate, reaching maximum (underestimate) oyster densities of $500 \pm 158 \mathrm{ind} \cdot \mathrm{m}^{-2}$. The occurrence of substantial oyster growth and related biostromal deposits, including valve embedding into hydrocarbon-imprinted limestone was noticed previously [67].

(ii) Vieste (Figure 1) presents a different situation, with smaller reefs, 1-2 $\mathrm{m}$ in length and width, and maximum height of 0.5-1 m; here, oyster density attains ca. $200 \pm 158 \mathrm{ind} \cdot \mathrm{m}^{-2}$ (Figure 2c,d).

(iii) At Monopoli and Santa Maria di Leuca sites (Figures 1 and 3), the latter in Ionian waters, it is difficult to estimate reef dimensions. In fact, at both sites $N$. cochlear grows on a rocky substrate and covers this primary substrate for several meters, growing thicker than $10-20 \mathrm{~cm}$. However, oyster densities are comparable with the Adriatic sites mentioned above.

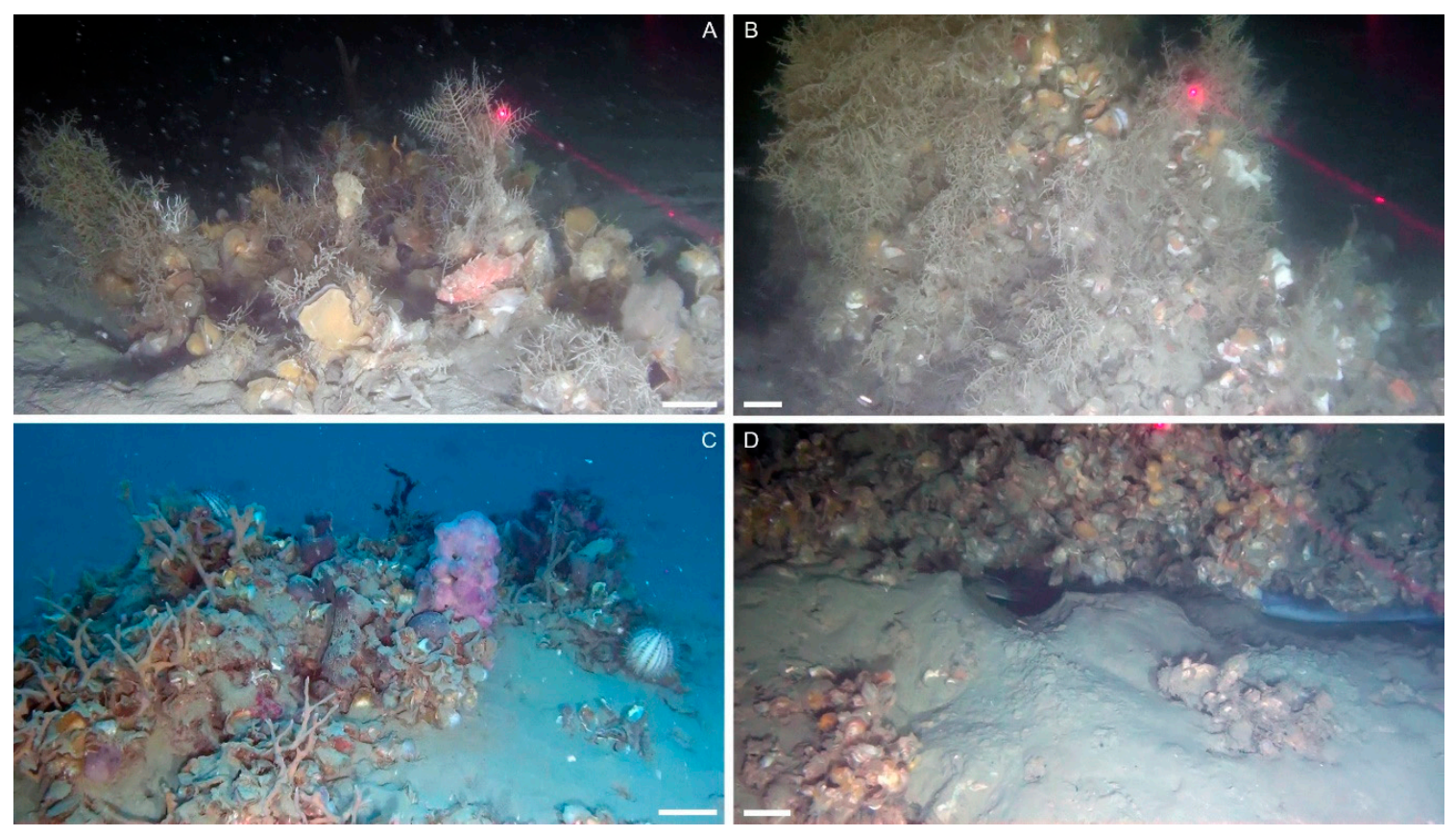

Figure 2. Different typologies of Neopycnodonte cochlear reefs on the Adriatic shelf. (A) Cluster of $N$. cochlear surrounded by muddy bottom, with hydrozoan turf and a juvenile Scorpaena scrofa, at ca. $80 \mathrm{~m}$ (Bonaccia); bar $=5 \mathrm{~cm}$. (B) Close-up on an oyster-densely-packed Neopycnodonte cochlear reef (up to $3 \mathrm{~m}$ high) with a dense hydrozoan turf coverage at $80 \mathrm{~m}$ (Bonaccia); bar $=5 \mathrm{~cm}$. (C) Neopycnodonte cochlear reef at $55 \mathrm{~m}$ (Vieste) showing intense oyster growth and the presence of the massive-globose cf. Petrosia sp. and the erected sponge Ulosa stuposa. The echinoid Echinus melo is a member of the associated vagrant fauna; bar $=10 \mathrm{~cm}$. (D) Base of a Neopycnodonte cochlear reef at $75 \mathrm{~m}$ (Vieste) providing shelter to a large Conger conger individual; bar $=5 \mathrm{~cm}$. 

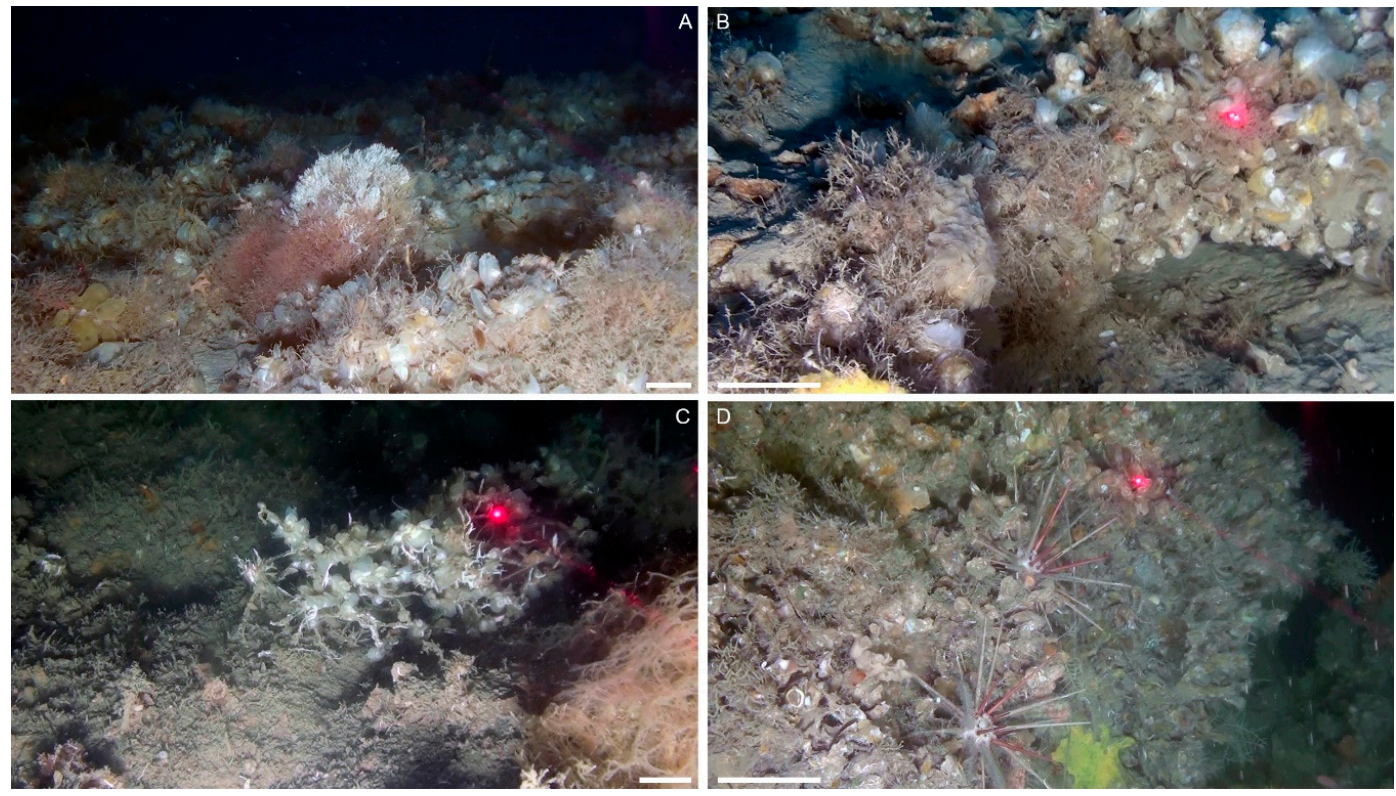

Figure 3. Different typologies of Neopycnodonte cochlear reefs in the southern Adriatic and northern Ionian Apulian shelf. (A) Dense Neopycnodonte growth on a flat sea-bottom at ca. $90 \mathrm{~m}$ (Monopoli), offering substrate for the colonial polychaete belonging to Filograna-Salmacina complex, undetermined bryozoans and hydrozoans turf; bar $=10 \mathrm{~cm}$. (B) Close-up of (A) imaging the density of N. cochlear at this site; bar $=3 \mathrm{~cm}$. (C) Juvenile specimens of $N$. cochlear colonizing a derelict fishing gear at $100 \mathrm{~m}$ (Santa Maria di Leuca) document quick oyster colonization of hard substrates here; $b a r=3 \mathrm{~cm}$. (D) The large Neopycnodonte cochlear reef situated at $100 \mathrm{~m}$ depth off Santa Maria di Leuca, displays dense oyster aggregation with reduced space for colonization by other epifauna; notice the vagrant echinoid Cidaris cidaris as grazing on oyster substrate; bar $=10 \mathrm{~cm}$.
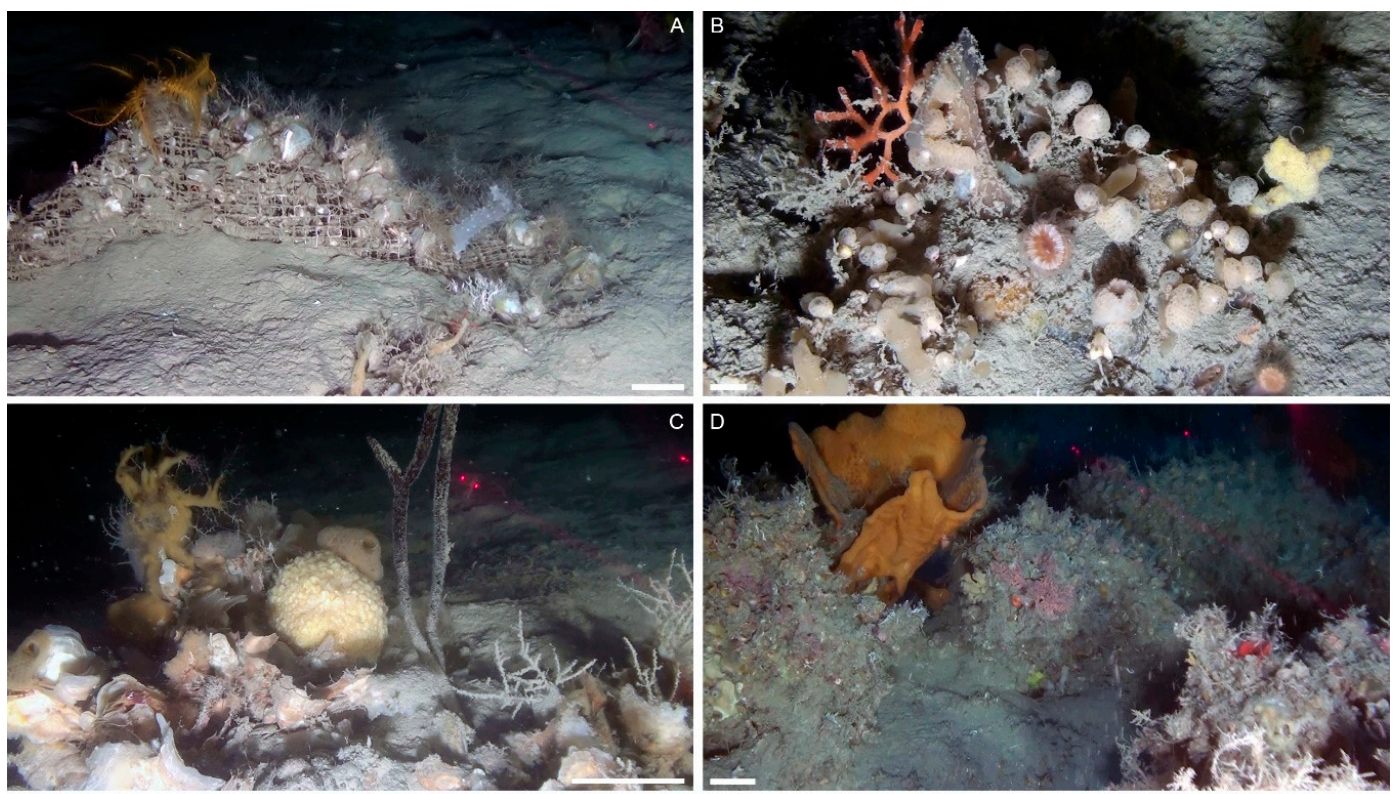

Figure 4. Examples of biodiversity of Neopycnodonte cochlear reefs. (A) Cluster of N. cochlear growing on a lost fishing net with Antedon mediterranea (left side) and Alcyonium palmatum (Monopoli); bar $=3 \mathrm{~cm}$. (B) Caryophyllia sp., Smittina cervicornis and undetermined lolli-pop and yellow sponges growing on cluster of $N$. cochlear at Monopoli site; bar $=3 \mathrm{~cm}$. (C) The golf ball sponge Tethya aurantium, protected by the SPAMI directive, is a relatively common record on $N$. cochlear reef (Bonaccia) at $83 \mathrm{~m}$; bar $=5 \mathrm{~cm}$. (D) A dense N. cochlear reef hosting the large fan-shaped sponge cf. Pachastrella sp. at ca. $120 \mathrm{~m}$ (Santa Maria di Leuca); bar $=10 \mathrm{~cm}$. 


\subsection{A Glimpse at Reefs' Associated Biodiversity}

The overall biodiversity associated with the Neopycnodonte cochlear reef is noticeable (Figures 2-5 and Table 2). Sponges dominate the macro- and mega-benthic associated fauna; Spongia officinalis, S. lamella, Axinella polypoides, Tethya aurantium (All listed in Annex II of the Barcelona Convention; if protected, they are so by the regulations of the countries who signed the Convention) and Ulosa stuposa are a common occurrence at Bonaccia and Vieste sites. Undetermined encrusting sponges characterize Monopoli and Santa Maria di Leuca, and A. cannabina and T. aurantium were recorded here. Cnidarians represent another dominant component, with all Neopycnodonte reefs surveyed by ROV showing high densities of hydroid turf, mostly cf. Halecium sp. and cf. Sertularella sp.; the scleractinian cupcoral Caryophyllia sp. has been spotted at all such sites, whilst Alcyonium palmatum characterizes the Monopoli site. The bryozoan Smittina cervicornis is easily recognizable at Monopoli and Santa Maria di Leuca, together with the colonial polychaete belonging to Filograna-Salmacina complex, while the solitary Sabella spallanzanii seems more abundant at Vieste and Bonaccia sites. A nudibranch in the family Tritoniidae and belonging to Marionia blainvillea was observed grazing on muddy sediment around $N$. cochlear reef at Vieste site. Finally, the tunicates Halocynthia papillosa and the colonial Botrylloides sp. occurs at all Neopycnodonte reef sites. The echinoids Echinus melo and Cidaris cidaris were identified at all sites, while the hatpin urchin Centrostephanus longispinus, a protected species (RAC/SPA and SPAMI), was a frequent sight at Vieste site; the crinoid Antedon mediterranea was recorded only at Monopoli site. Regarding fish, we have observed the small labrid Serranus cabrilla, documented at all sites, whilst Scorpaena scrofa and Conger conger are relatively common at Bonaccia and Vieste sites, respectively.
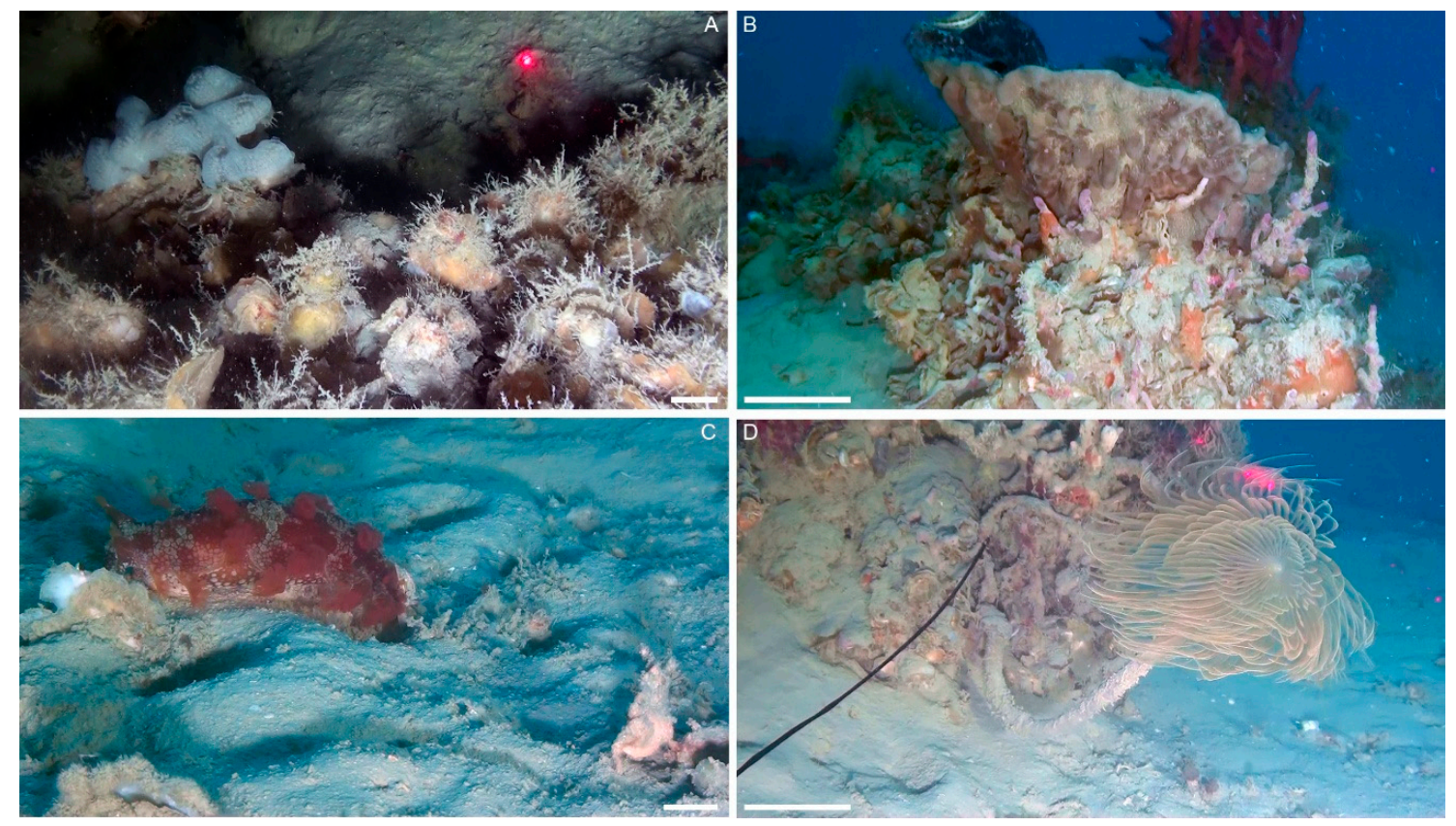

Figure 5. Examples of biodiversity of Neopycnodonte cochlear reefs. (A) The colonial tunicate cf. Diplosoma spongiforme on top of small N. cochlear bed, surrounded by a hydrozoan turf at $70 \mathrm{~m}$ (Vieste); bar $=3 \mathrm{~cm}$. (B) Spongia lamella, Axinella polypoides and Ulosa stuposa are common findings at ca $60 \mathrm{~m}$ (Vieste) on Neopycnodonte reef; bar $=10 \mathrm{~cm}$. (C) Marionia blainvillea (family Tritoniidae) grazing on muddy sediment around the N. cochlear reef at $50 \mathrm{~m}$ (Vieste); bar $=1 \mathrm{~cm}$. (D) Sabella spallanzanii growing at the base of a m-thick Neopycnodonte reef at $60 \mathrm{~m}$ (Vieste); bar $=5 \mathrm{~cm}$. 
Table 2. Living macro-organisms observed in the ROV surveyed areas. The numbers indicate the legal instruments under which the species are protected: 1-SPAMI Annex II, III (Specially Protected Areas of Mediterranean Importance); 2-Italian Red List IUCN; 3-Red List IUCN; 4-CITES Appendix II (Convention on International Trade in Endangered Species of Wild Fauna and Flora); 5-Habitat Directive Annex II, IV, V; 6-Bern Convention, Appendix II, III (Convention on the Conservation of European Wildlife and Natural Habitats).

\begin{tabular}{|c|c|c|c|c|c|}
\hline n. & Phylum & Class & Taxon & Auctores & Protection \\
\hline 1 & \multirow[t]{19}{*}{ Porifera } & \multirow[t]{19}{*}{ Demospongiae } & spp. & & \\
\hline 2 & & & Aplysina aerophoba & (Nardo, 1833) & 1 \\
\hline 3 & & & Axinella cannabina & (Esper, 1794) & $1,2(\mathrm{EN})$ \\
\hline 4 & & & Axinella polypoides & Schmidt, 1862 & $1,2(\mathrm{EN}), 6$ \\
\hline 5 & & & Cliona celata & Grant, 1826 & \\
\hline 6 & & & Haliclona mediterranea & Griessinger, 1971 & \\
\hline 7 & & & Hexadella racovitzai & Topsent, 1896 & \\
\hline 8 & & & Ircinia variabilis & Schmidt, 1862 & \\
\hline 9 & & & Mycale tunicata & Schmidt, 1862 & \\
\hline 10 & & & cf. Petrosia sp. & & \\
\hline 11 & & & Poecillastra compressa & $\begin{array}{c}\text { (Bowerbanck, } \\
1866)\end{array}$ & 2 (VU) \\
\hline 12 & & & Spongia spp. & & \\
\hline 13 & & & cf. Spongia agaricina & Pallas, 1766 & 1,6 \\
\hline 14 & & & Spongia lamella & (Schulze, 1879) & $2(\mathrm{EN})$ \\
\hline 15 & & & Spongia officinalis & Linnaeus, 1759 & $1,2(\mathrm{EN}), 6$ \\
\hline 16 & & & Suberites domuncula & (Olivi, 1792) & \\
\hline 17 & & & Tethya aurantium & (Pallas, 1766) & \\
\hline 18 & & & Tethya cf. citrina & $\begin{array}{c}\text { Sarà and Melone, } \\
1965\end{array}$ & 1 \\
\hline 19 & & & Ulosa stuposa & (Esper, 1794) & \\
\hline 20 & \multirow[t]{11}{*}{ Cnidaria } & \multirow[t]{4}{*}{ Hydrozoa } & cf. Halecium sp. & & \\
\hline 21 & & & cf. Halecium halecinum & (Linnaeus, 1758) & \\
\hline 22 & & & Lytocarpia myriophyllum & (Linnaeus, 1758) & \\
\hline 23 & & & cf. Sertularella sp. & & \\
\hline 24 & & \multirow[t]{7}{*}{ Anthozoa } & Alcyonium palmatum & Pallas, 1766 & \\
\hline 25 & & & Caryophyllidae spp. & & \\
\hline 26 & & & Caryophyllia cf. smithii & $\begin{array}{c}\text { Stokes and } \\
\text { Broderip, } 1828\end{array}$ & 4 \\
\hline 27 & & & Dendrophyllia cornigera & (Lamarck, 1816) & $\begin{array}{l}2(\mathrm{VU}), 3 \\
(\mathrm{EN}), 4\end{array}$ \\
\hline 28 & & & Paralcyonium spinulosum & $\begin{array}{c}\text { (Delle Chiaje, } \\
\text { 1822) }\end{array}$ & \\
\hline 29 & & & Phyllangia americana & $\begin{array}{l}\text { Milne Edwards } \\
\text { and Haime, } 1849\end{array}$ & 4 \\
\hline 30 & & & Virgularia mirabilis & (Müller, 1776) & 2 (VU), \\
\hline 31 & \multirow[t]{7}{*}{ Annelida } & \multirow[t]{7}{*}{ Polychaeta } & Bonellia viridis & Rolando, 1822 & \\
\hline 32 & & & Filograna-Salmacina complex & & \\
\hline 33 & & & Protula tubularia & (Montagu, 1803) & \\
\hline 34 & & & Sabella spallanzanii & (Gmelin, 1791) & \\
\hline 35 & & & Serpula vermicularis & Linnaeus, 1767 & \\
\hline 36 & & & Terebellides stroemii & Sars, 1835 & \\
\hline 37 & & & Vermiliopsis sp. & & \\
\hline 38 & \multirow[t]{8}{*}{ Mollusca } & Bivalvia & Atrina fragilis & (Pennant, 1777) & \\
\hline 39 & & & Neopycnodonte cochlear & (Poli, 1795) & \\
\hline 40 & & \multirow{5}{*}{ Gastropoda } & Pecten jacobaeus & (Linnaeus, 1758) & \\
\hline 41 & & & cf. Calliostoma zizyphinum & (Linnaeus, 1758) & \\
\hline 42 & & & cf. Fusinus sp. & & \\
\hline 43 & & & Hexaplex trunculus & (Linnaeus, 1758) & \\
\hline 44 & & & cf. Naticidae & & \\
\hline 45 & & Nudibranchia & cf. Caloria elegans & $\begin{array}{c}\text { (Alder and } \\
\text { Hancock, 1845) }\end{array}$ & \\
\hline
\end{tabular}


Table 2. Cont.

\begin{tabular}{|c|c|c|c|c|c|}
\hline n. & Phylum & Class & Taxon & Auctores & Protection \\
\hline 46 & & & Flabellina affinis & (Gmelin, 1791) & \\
\hline 47 & & & Hypselodoris tricolor & (Cantraine, 1835) & \\
\hline 48 & & & Marionia blainvillea & (Risso, 1818) & \\
\hline 49 & & Cephalopoda & cf. Octopus vulgaris & Cuvier, 1797 & \\
\hline 50 & & & Teuthida sp. & & \\
\hline 51 & Arthropoda & Malacostraca & Maja squinado & (Herbst, 1788) & 1,6 \\
\hline 52 & & & Munida sp. & & \\
\hline 53 & & & Pagurus cf. excavatus & (Herbst, 1791) & \\
\hline 54 & & & Palinurus elephas & (Fabricius, 1787) & 1,3 (VU), 6 \\
\hline 55 & Bryozoa & Gymnolaemata & Reteporella grimaldii & (Jullien, 1903) & \\
\hline 56 & & & Smittina cervicornis & (Pallas, 1766) & \\
\hline 57 & Echinoderma & ataAsteroidea & Chaetaster longipes & (Bruzelius, 1805) & \\
\hline 58 & & & Echinaster sepositus & (Retzius, 1783) & \\
\hline 59 & & & Marthasterias glacialis & (Linnaeus, 1758) & \\
\hline 60 & & & Peltaster placenta & $\begin{array}{c}\text { (Müller and } \\
\text { Troschel, 1842) }\end{array}$ & \\
\hline 61 & & Crinoidea & Antedon mediterranea & (Lamarck, 1816) & \\
\hline 62 & & Echinoidea & Centrostephanus longispinus & (Philippi, 1845) & $1,5,6$ \\
\hline 63 & & & Cidaris cidaris & (Linnaeus, 1758) & \\
\hline 64 & & & Echinus melo & Lamarck, 1816 & \\
\hline 65 & & Holothuroidea & Holothuria forskali & Delle Chiaje, 1823 & \\
\hline 66 & & Ophiuroidea & cf. Ophiothrix fragilis & $\begin{array}{l}\text { (Abildgaard in } \\
\text { Müller, 1789) }\end{array}$ & \\
\hline 67 & Chordata & Ascidiacea & sp. & & \\
\hline 68 & & & Botrylloides sp. & & \\
\hline 69 & & & Didemnidae sp. & & \\
\hline 70 & & & Diplosoma spongiforme & (Giard, 1872) & \\
\hline 71 & & & Halocynthia papillosa & (Linnaeus, 1767) & \\
\hline 72 & & Actinopterygii & Callanthias ruber & $\begin{array}{c}\text { (Rafinesque, } \\
\text { 1810) }\end{array}$ & \\
\hline 73 & & & Chelidonichthys lastoviza & $\begin{array}{c}\text { (Bonnaterre, } \\
\text { 1788) }\end{array}$ & \\
\hline 74 & & & Conger conger & (Linnaeus, 1758) & \\
\hline 75 & & & Muraena helena & Linnaeus, 1758 & \\
\hline 76 & & & Phycis phycis & (Linnaeus, 1766) & \\
\hline 77 & & & Serranus cabrilla & (Linnaeus, 1758) & \\
\hline 78 & & & Scorpaena scrofa & Linnaeus, 1758 & \\
\hline 79 & & & Spicara maena & (Linnaeus, 1758) & \\
\hline
\end{tabular}

\section{Discussion}

As exhaustively documented in the literature, oyster reefs serve as habitat refuge for many organisms like decapods and echinoids among invertebrates, and fishes among vertebrates often hosting species of commercial interest (e.g., [3-7,54-57,60,68]).

The Neopycnodonte cochlear reefs in the central and eastern Mediterranean represent also a hotspot of biodiversity, as well as are the transitional areas between Neopycnodonte reefs and surrounding mobile sediment bottom. Lastly, these reefs are home to protected species such as Centrostephanus longispinus, recorded by the ROV surveys.

Despite intense investigation on littoral oyster reefs (e.g., Ostrea edulis $[54,56,57,60]$ ), information on intermediate Neopycnodonte cochlear reefs is still exiguous. The development and improvement of non-invasive technologies (i.e., ROV), coupled with high-definition image acquisition, has paradoxically provided more knowledge on deep Neopycnodonte zibrowii oyster occurrences $(>200 \mathrm{~m})$ than on Neopycnodonte cochlear reefs at intermediate depths $(30-150 \mathrm{~m})$. The monitoring program under the Marine Strategy Framework Directive does not consider Neopycnodonte cochlear reefs among target habitats. Further research is needed to better understand such reefs, to expand our knowledge about their spatial distribution, associated biodiversity, and goods and services they may provide. 
The Neopycnodonte cochlear reefs are not considered among the top marine bioconstructions listed by [69]. Their ecosystemic importance, however, strongly advises for the enforcement of adequate management measures to ensure their survival, including fishery restrictions. In fact, the impact by trawling and longlining on oyster reefs cannot be a priori excluded in consideration of the fishery effort in this region (e.g., [70-72]). This approach would be in line with European recommendations for "H1170 Reefs" in the Annex I of the Habitats Directive 92/42/EEC on the conservation of natural habitats and of wild fauna and flora [73]. The inclusion in protected areas of the sites of Bonaccia, Vieste, Monopoli and Santa Maria di Leuca would guarantee the preservation of examples of grypheid reefs growing at different depths and substrates and encompassing slightly different biodiversity content.

\section{Conclusions}

Albeit relatively neglected thus far, oyster reefs engineered by the grypheid Neopycnodonte cochlear are important bioconstructions in the mesophotic zone of the Mediterranean Sea.

Remarkable examples of such reefs occur in the Adriatic and Ionian waters from $40 \mathrm{~m}$ down to 130 meters. ROV inspection of these Neopcynodonte cochlear reefs testifies to dense oyster growth and considerable biodiversity of the associated fauna calling for their protection.

Author Contributions: Both Authors have equally contributed to the conceptualization and writing of the present article. All authors have read and agreed to the published version of the manuscript.

Funding: This work was partly supported by the EU FP-VI and VII HERMES and HERMIONE, by the 'Convenzione MATTM-CNR per i Programmi di Monitoraggio per la Direttiva sulla Strategia Marina (MSFD, Art. 11, Dir. 2008/56/CE), and is part of the DG Environment programme IDEM (grant agreement no. 11.0661/2017/750680/SUB/EN V.C2).

Acknowledgments: We thank captain, crew, and scientific staff of RR/VV Urania and Minerva Uno for their skillful and efficient cooperation during operations at sea. English language kindly revised by Todd Bond (UWA, Perth). We acknowledge three anonymous reviewers, which helped to improve the clarity of this manuscript. This is ISMAR-Bologna scientific contribution n. 2021.

Conflicts of Interest: The authors declare no conflict of interest.

\section{References}

1. Galtsoff, P.S. The American oyster, Crassostrea virginica Gmelin. Fish. Bull. 1964, 64, 1-488.

2. Stenzel, H.B. Oyster. In Treatise on Invertebrate Paleontology; Part N, Volume 3, Mollusca 6, Bivalvia; Moore, R.C., Ed.; Geological Society of America and University of Kansas. Boulder \& Lawrence: Lawrence, MA, USA, 1971; pp. 953-1224.

3. Lenihan, H.S.; Peterson, C.H. How habitat degradation through fishery disturbance enhances impacts of hypoxia on oyster reefs. Ecol. Appl. 1998, 8, 28-140. [CrossRef]

4. Gutierrez, A.P.; Turner, F.; Gharbi, K.; Talbot, R.; Lowe, N.R.; Peñaloza, C.; McCullough, M.; Prodöhl, P.A.; Bean, T.P.; Houston, R.D. Development 470 of a Medium Density Combined-Species SNP Array for Pacific and European oysters (Crassostrea gigas and Ostrea edulis). G3 Genes Genomes Genet. 2017, 7, 2209-2218.

5. Piazza, B.P.; Bank, P.D.; La Peyre, M.K. The potential for created oyster shell reefs as a sustainable shoreline protection strategy in Louisiana. Restor. Ecol. 2005, 13, 499-506. [CrossRef]

6. Ruesink, J.L.; Lenihan, H.S.; Trimble, A.C.; Heiman, K.W.; Micheli, F.; Byers, J.E.; Kay, M.C. Introduction of non-native oysters: Ecosystem effects and restoration implications. Ann. Rev. Ecol. Evol. Syst. 2005, 36, 643-689. [CrossRef]

7. Tolley, S.G.; Volety, A.K. The role of oysters in habitat use of oyster reefs by resident fishes and decapod crustaceans. J. Shellfish Res. 2005, 24, 1007-1012.

8. Kochmann, J.; Buschbaum, C.; Volkenborn, N.; Reise, K. Shift from native mussels to alien oysters: Differential effects of ecosystem engineers. J. Exp. Mar. Biol. Ecol. 2008, 364, 1-10. [CrossRef]

9. Markert, A.; Wehrmann, A.; Kroncke, I. Recently established Crassostrea-reefs versus native Mytilus-beds: Differences in ecosystem engineering affects the macrofaunal communities (Wadden Sea of Lower Saxony, southern German Bight). Biol. Invasions 2010, 12, 15-32. [CrossRef] 
10. Grabowski, J.H.; Brumbaugh, R.D.; Conrad, R.F.; Keeler, A.G.; Opaluch, J.J.; Peterson, C.H.; Piehler, M.F.; Powers, S.P.; Smyth, A.R. Economic Valuation of ecosystem services provided by oyster reefs. BioScience 2012, 62, 900-909. [CrossRef]

11. Walles, B.; de Paiva, J.S.; van Prooijen, B.C.; Ysebaer, T.; Smaal, A.C. The ecosystem engineer Crassostrea gigas affects tidal flat morphology beyond the boundary of their reef structures. Estuaries Coasts 2015, 38, 941-950. [CrossRef]

12. Beck, M.W.; Brumbaugh, R.D.; Airoldi, L.; Carranza, A.; Coen, L.D.; Crawford, C.; Defeo, O.; Edgar, G.J.; Hancock, B.; Kay, M.C.; et al. Oyster reefs at risk and recommendations for conservation, restoration, and management. BioScience 2011, 61, 107-116. [CrossRef]

13. Bahr, L.N.; Lanier, W.P. The Ecology of Intertidal Oyster Reefs of the South Atlantic Coast: A Community Profile; U.S. Fish and Wildlife Service, Office of Biological Services: Washington, DC, USA, 1981.

14. Drinkward, A.C. Introductions and developments of oysters in the North Sea area: A review. Helgol. Meeres. 1999, 52, 301-308. [CrossRef]

15. Bayne, B. Biology of Oysters; Academic Press: London, UK, 2017; p. 860.

16. Guo, X.; Cui, L.; Wang, H.; Xu, Z. Diversity and evolution of living oysters. J. Shellfish Res. 2018, 37, 755-771. [CrossRef]

17. Fürsich, F.T. Palaeoecology and evolution of Mesozoic salinity-controlled benthic macroinvertebrate associations. Lethaia 1993, 26, 327-346. [CrossRef]

18. Geyer, G.; Herbig, H.G. New Eocene oysters and the final regression at the southern rim of the central high Atlas (Morocco). Geobios 1988, 21, 663-691. [CrossRef]

19. Seilacher, A.; Matyja, B.A.; Wierzbowski, A. Oyster beds: Morphologic response to changing substrate conditions. In Sedimentary and Evolutionary Cycles, Lect. Notes Earth Scie; Book Series (LNEARTH, Volume 1); Springer: Berlin/Heidelberg, Germany, 2005; pp. 421-435.

20. Machalski, M. Oyster life positions and shell beds from the Upper Jurassic of Poland. Acta Paleontol. Pol. 1998, 43, 609-634.

21. Beu, A.G.; Raine, J.I. Revised Descriptions of New Zealand Cenozoic Mollusca from Beu and Maxwell; GNS Science Miscellaneous Series no. 27; Publications Officer, GNS Science: Lower Hutt, New Zealand, 2009; Available online: https://www.gns.cri.nz/static/Mollusca/ (accessed on 29 December 2019).

22. MacMillan, L.C. Comparative Sedimentology and Paleoecology of Fossil Giant Oyster Beds in Some Tertiary Strata of New Zealand and Argentina. Master's Thesis, The University of Waikato, Hamilton, New Zealand, 2010. Available online: http://waikato.researchgateway.ac.nz/ (accessed on 20 December 2019).

23. Harzhauser, M.; Djuricic, A.; Mandic, O.; Neubauer, T.A.; Zuschin, M.; Pfeifer, N. Age structure, carbonate production and shell loss rate in an Early Miocene reef of the giant oyster Crassostrea gryphoides. Biogeosciences 2016, 13, 1223-1235. [CrossRef]

24. Pufahl, P.K.; James, N.P. Monospecific Pliocene oyster buildups, Murray Basin, South Australia: brackish water end member of the reef spectrum. Palaeogeogr. Palaeoclim. Palaeoecol. 2006, 233, 11-33. [CrossRef]

25. Royal Commission. Report of the Commissioners: Trawl Net and Beam Trawl Fishing with Minutes of Evidence and Appendix; Eyre and Spottiswoode: London, UK, 1885.

26. Pérès, J.M.; Picard, J. Nouveau manuel de bionomie benthique. Rec. Trav. Stat. Mar. Endoume. 1964, 31, $1-137$.

27. Parenzan, P. Storia della Crassostrea gigas (Thumb.) spontanea nel Mediterraneo. Thalass. Salent. 1969, 19, $39-48$.

28. Poluzzi, A.; Sabelli, B.; Taviani, M. Autosinecologia dei molluschi dei fondi mobili del Delta settentrionale del Po (estate 1980). Boll. Soc. Paleontol. Ital. 1981, 21, 169-178.

29. FAO. Cultured Aquatic Species Information Programme. Crassostrea Gigas. Available online: http://www.fao. org/fishery/culturedspecies/Crassostrea_gigas/en (accessed on 31 December 2019).

30. Smaal, A.C.; Kater, B.J.; Wijsman, J. Introduction, establishment and expansion of the Pacific oyster Crassostrea gigas in the Oosterschelde (SW Netherlands). Helgol. Mar. Res. 2009, 63, 75-83. [CrossRef]

31. Todorova, V.; Micu, D.; Klisurov, L. Unique oyster reef discovered in the Bulgarian Black Sea. CR. Acad. Bulg. Sci. 2009, 62, 871-874.

32. Troost, T.K. Causes and effects of a highly successful marine invasion: Case-study of the introduced Pacific oyster Crassostrea gigas in continental NW European estuaries. J. Sea Res. 2010, 64, 145-165. [CrossRef] 
33. Wrange, A.-L.; Valero, J.; Harkestad, L.S.; Strand, O.; Lindegarth, S.; Christensen, H.T.; Dolmer, P.; Kristensen, P.S.; Mortensen, S. Massive settlements of the Pacific oyster, Crassostrea gigas, in Scandinavia. Biol. Inv. 2010, 12, 1145-1152. [CrossRef]

34. Lejart, M.; Hilly, C. Differential response of benthic macrofauna to the formation of novel oyster reefs (Crassostrea gigas, Thunberg) on soft and rocky substrate in the intertidal of the Bay of Brest, France. J. Sea Res. 2011, 65, 84-93. [CrossRef]

35. Taviani, M.; Roveri, M.; Impiccini, R.; Vigliotti, L. Segnalazione di Quaternario marino nella Val Chero (Appennino piacentino). Boll. Soc. Paleont. Ital. 1997, 36, 331-338.

36. Dominici, S.; Benvenuti, M.; Forli, M.; Bogi, C.; Guerrini, A. Upper Miocene molluscs of Monti Livornesi (Tuscany, Italy): Biotic changes across environmental gradients. Palaeogeogr. Palaeoclim. Palaeoecol. 2019, 527, 103-117. [CrossRef]

37. Ceregato, A.; Raffi, S.; Scarponi, D. The circalittoral/bathyal paleocommunities in the Middle Pliocene of Northern Italy: The case of the Korobkovia oblonga-Jupiteria concava paleocommunity type. Geobios 2007, 40, 555-572. [CrossRef]

38. Studencka, B.; Jasionowski, M. Bivalves from Middle Miocene reefs of Poland and Ukraine: A new approach to Badenian/Sarmatian boundary in the Paratethys. Acta Geol. Pol. 2011, 61, 79-114.

39. Górka, M.; Studencka, B.; Jasionowski, M.; Hara, U.; Wysocka, A.; Poberezhskyy, A. The Medobory Hills (Ukraine): Middle Miocene reef systems in the Paratethys, their biological diversity and lithofacies. Biul. Panst. In. Geol. 2012, 449, 147-174.

40. Freiwald, A.; Beuck, L.; Rüggeberg, A.; Taviani, M.; Hebbeln, D.; R/V METEOR Cruise M70-1 Participants. The white coral community in the central Mediterranean revealed by ROV surveys. Oceanography 2009, 22, 58-74. [CrossRef]

41. Wisshak, M.; López Correa, M.; Gofas, S.; Salas, C.; Taviani, M.; Jakobsen, J.; Freiwald, A. Shell architecture, element composition, and stable isotope signature of the giant deep-sea oyster Neopycnodonte zibrowii sp. $\mathrm{n}$. from the NE Atlantic. Deep Sea Res. Part I 2009, 56, 374-407. [CrossRef]

42. Gofas, S.; Rueda, J.L.; Salas, C.; Díaz-del-Río, V. A new record of the giant deep-sea oyster Neopycnodonte zibrowii in the Gulf of Cadiz (south-western Iberian Peninsula). Mar. Biodiv. Rec. 2010, 3, 1-4. [CrossRef]

43. Van Rooij, D.; DeMol, L.; LeGuilloux, E.; Wisshak, M.; Huvenne, V.A.I.; Moeremans, R.; Henriet, J.-P. Environmental setting of deep-water oysters in the Bay of Biscay. Deep Sea Res. Part I 2010, 57, 1561-1572. [CrossRef]

44. Beuck, L.; Aguilar, R.; Fabri, M.-C.; Freiwald, A.; Gofas, S.; Hebbeln, D.; López Correa, M.; Ramos, A.; Ramil, F.; Sánchez, F.; et al. Biotope characterisation and compiled geographical distribution of the deep-water oyster Neopycnodonte zibrowii in the Atlantic Ocean and Mediterranean Sea. Rapp. Comm. Intern. Mer Médit. 2016, 41, 462.

45. Aguilar, R.; Pilar, M.; Gerovasileiou, V. Draft Guidelines for Inventoring and Monitoring of Dark Habitats; UNEP(DEPI)/MED WG. 431/Inf.12, Thirteenth Meeting of Focal Points for Specially Protected Areas. Agenda Item 4: Progress report on activities carried out by SPA/RAC since the twelfth meeting of Focal Points for SPAs. United Nations Environment Programme/Mediterranean Action Plan (UN Environment /MAP); Specially Protected Areas Regional Activity Centre (SPA/RAC): Alexandria, Egypt, 2017; pp. 1-55.

46. Fourt, M.; Goujard, A.; Perez, T.; Chevaldonné, P. Guide de la faune profonde de la mer Méditerranée. Exploration des roches et canyons sous-marins des côtes françaises; Muséum National d'Histoire Naturelle: Paris, France, 2017; pp. 1-184.

47. Taviani, M.; Angeletti, L.; Cardone, F.; Montagna, P.; Danovaro, R. A unique and threatened deep water coral-bivalve biotope new to the Mediterranean Sea offshore the Naples megalopolis. Sci. Rep. 2019, 9, 12. [CrossRef]

48. Gofas, A.; Freiwald, A.; López Correa, M.; Remia, A.; Salas, C.C.; Taviani, M.; Wisshak, M.; Zibrowius, H. Oyster beds in the deep sea. In Abstracts World Congress of Malacology; Jordaens, K., Van Houtte, N., Van Goethem, J., Backeljau, T., Eds.; Unitas Malacologica: Antwerp, Belgium, 2007; pp. 80-82.

49. Le Danois, E. Les Profondeurs De La Mer; Payot: Paris, France, 1948; pp. 1-303.

50. Onorato, R.; Forti, P.; Belmonte, G.; Poto, M.; Costantini, A. La grotta sottomarina Lu Lampiune: novità esplorative. Thalassia Salent. 2003, 26, 55-64. 
51. Taviani, M.; Angeletti, L.; Campiani, E.; Ceregato, A.; Foglini, F.; Maselli, V.; Morsilli, M.; Parise, M.; Trincardi, F. Drowned karst landscape offshore the Apulian margin (Southern Adriatic Sea, Italy). J. Cave Karst Stud. 2012, 74, 197-212. [CrossRef]

52. Corriero, G.; Pierri, C.; Mercurio, M.; Marzano, C.N.; Tarantini, S.O.; Gravina, M.F.; Lisco, S.; Moretti, M.; De Giosa, F.; Valenzano, E.; et al. Mediterranean mesophotic coral reef built by non-symbiotic scleractinians. Sci. Rep. 2019, 9, 3601. [CrossRef] [PubMed]

53. Sotomayor-García, A.; Rueda, J.L.; Sánchez-Guillamón, O.; Urra, J.; Vázquez, J.T.; Palomino, D.; Fernández-Salas, L.M.; López-González, N.; González-Porto, M.; Santana-Casiano, J.M.; et al. First macro-colonizers and survivors around Tagoro Submarine Volcano, Canary Islands, Spain. Geosciences 2019, 9, 52. [CrossRef]

54. Rodriguez, A.B.; Fodire, J.F.; Ridge, J.T.; Lindquist, N.L.; Theuerkauf, E.J.; Coleman, S.E.; Grabowski, J.H.; Brodeur, M.C.; Gittman, R.K.; Keller, D.A.; et al. Oyster reefs can outpace sea-level rise. Nat. Clim. Chang. 2014, 4, 493-497. [CrossRef]

55. Peters, J.W.; Eggleston, D.B.; Puckett, B.J.; Theuerkauf, S.J. Oyster demographics in harvested reefs vs. no-take reserves: Implications for larval spillover and restoration success. Front. Mar. Sci. 2017, 4, 326. [CrossRef]

56. Ridge, J.T.; Rodriguez, A.B.; Fodrie, F.J. Evidence of exceptional oyster-reef resilience to fluctuations in sea level. Ecol. Evol. 2019, 7, 10409-10420. [CrossRef] [PubMed]

57. Southwell, M.W.; Veenstra, J.J.; Adams, C.D.; Scarlett, E.V.; Payne, K.B. Changes in sediment characteristics upon oyster reef restoration, NE Florida, USA. J. Coast. Zone Manag. 2017, 20, 442. [CrossRef]

58. Smaal, A.C.; Ferreira, J.G.; Grant, J.; Petersen, J.K.; Strand, Ø. Goods and Services of Marine Bivalves; Springer International Publishing, Springer Nature Switzerland AG: Cham, Switzerland, 2019; pp. 1-598. [CrossRef]

59. European Commission. Interpretation Manual of European Union Habitats; EUR 28; European Commission, DG Environment, Nature ENV B.3 2013. p. 144. Available online: http://ec.europa.eu/environment/nature/ legislation/habitatsdirective/docs/Int_Manual_EU28.pdf (accessed on 5 December 2019).

60. La Peyre, M.K.; Marshall, D.A.; Miller, L.S.; Humpries, A.T. Oyster reefs in Northern Gulf of Mexico estuaries harbor diverse fish and decapod crustacean assemblages: a meta-synthesis. Front. Mar. Sci. 2019, 6, 666. [CrossRef]

61. EUNIS. 1997. Available online: https://eunis.eea.europa.eu/habitats-code-browser.jsp (accessed on 28 December 2019).

62. EMODnet Bathymetry Consortium: EMODnet Digital Bathymetry (DTM). 2018. Available online: http: //www.emodnet-bathymetry.eu (accessed on 20 December 2019).

63. Foglini, F.; Grande, V.; Marchese, F.; Bracchi, V.A.; Prampolini, M.; Angeletti, L.; Castellan, G.; Chimienti, G.; Hansen, I.M.; Gudmunsen, M.; et al. Application of hyperspectral imaging to underwater habitat mapping, Southern Adriatic Sea. Sensors 2019, 19, 2261. [CrossRef]

64. Santín, A.; Grynó, J.; Ambroso, S.; Uriz, M.J.; Dominguez-Carrió, C.; Gili, J.-M. Distribution patterns and demographic trends of demosponges at the Menorca Channel (Northwestern Mediterranean Sea). Prog. Oceanogr. 2019, 173, 9-25.

65. WoRMS Editorial Board. 2019. Available online: http://www.marinespecies.org (accessed on 25 December 2019).

66. Bortoluzzi, G.; Gasperini, L.; Cagatay, N.; Gorur, N. Geophysical and Geological Studies in the Sea of Marmara and Gulf of Saros. ISMAR Bologna Technical Report, 98; Bologna, Italy, 2005; pp. 1-33. Available online: http://ricerca.ismar.cnr.it/CRUISE_REPORTS/2000-2009/MARM05_REP/MARM05_REP.pdf (accessed on 20 December 2019).

67. Taviani, M.; Franchi, F.; Angeletti, L.; Correggiari, A.; López Correa, M.; Maselli, V.; Mazzoli, C.; Peckmann, J. Biodetrital carbonates on the Adriatic continental shelf imprinted by oxidation of seeping hydrocarbons. Mar. Petrol. Geol. 2015, 66, 511-531. [CrossRef]

68. Harding, J.M.; Mann, R. Oyster reefs as fish habitat: opportunistic use of restored reefs by transient fishes. J. Shelf Res. 2001, 20, 951-959.

69. Ingrosso, G.; Abbiati, M.; Badalamenti, F.; Bavestrello, G.; Belmonte, G.; Cannas, R.; Benedetti-Cecchi, L.; Bertolino, M.; Bevilacqua, S.; Bianchi, C.N.; et al. Mediterranean bioconstructions along the Italian coast. Adv. Mar. Biol. 2018, 79, 61-136. [PubMed] 
70. Carlucci, R.; Lembo, G.; Maiorano, P.; Capezzuto, F.; Marano, C.A.; Sion, L.; Spedicato, M.T.; Ungaro, N.; Tursi, A.; D'Onghia, G. Nursery areas of red mullet (Mullus barbatus), hake (Merluccius merluccius) and deep-water rose shrimp (Parapenaeus longirostris) in Eastern-Central Mediterranean Sea. Estuar. Coast. Shelf Sci. 2009, 83, 529-538. [CrossRef]

71. FAO. The State of Mediterranean and Black Sea Fisheries; General Fisheries Commission for the Mediterranean: Rome, Italy, 2018; pp. 1-172. Available online: http://www.fao.org/3/ca2702en/CA2702EN.pdf (accessed on 5 February 2020).

72. Spedicato, M.T.; Zupa, W.; Carbonara, P.; Casciaro, L.; Bitetto, I.; Facchini, M.T.; Gaudio, P.; Palmisano, M.; Lembo, G. Lo stato delle risorse biologiche e della pesca nel Basso Adriatico e nello Ionio nord occidentale. In Atti del Convegno il Mare Adriatico e le sue Risorse; Marini, M., Bombace, G., Iacobone, G., Eds.; Carlo Saladino Editore: Palermo, Italy, 2017; pp. 177-208.

73. Council Directive 92/43/EEC—EUR-Lex. Available online: https://eur-lex.europa.eu/LexUriServ/LexUriServ. do?uri=OJ:L:1992:206:0007:0050:EN:PDF (accessed on 5 December 2019).

(C) 2020 by the authors. Licensee MDPI, Basel, Switzerland. This article is an open access article distributed under the terms and conditions of the Creative Commons Attribution (CC BY) license (http://creativecommons.org/licenses/by/4.0/). 